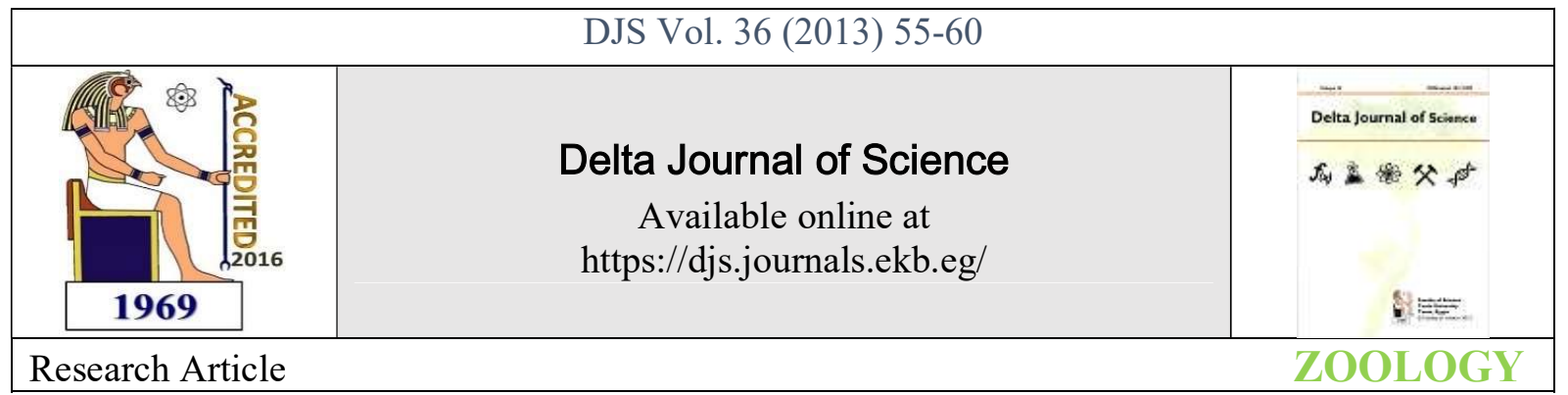

\title{
A study on incidence of thalassemia in Port Said - Egypt using complete blood counts (CBC), a modified osmotic fragility test (OF-test) and a direct PCR on whole blood cell lysates
}

\author{
Akram M. Abouzied ${ }^{1, \#}$, Amany A. Ibrahim², Ahmed A. El-Lwah ${ }^{3}$, Zohour I. Nabil ${ }^{1}$ \\ 1. Zoology Department, Faculty of Science, Suez Canal University, Ismailia, Egypt. 2. \\ Medical Lab El-Lwah, Saad Zaghloul St, Port Said, Egypt. 3. Department of Clinical \\ Pathology, Faculty of Medicine, Al-Azhar University, Cairo, Egypt.
}

Corresponding author: Akram M. Abouzied

Tel: 00201002848459

Fax: 0020643230416

email: abouakr@iit.edu

\section{ABSTRACT}

In order to study the incidence of thalassemia in Port Said - Egypt, we have used complete blood counts (CBC) and a combination of a modified onetube osmotic fragility test (OF-test) followed by a direct PCR analysis on whole blood cell lysates. One hundred and eighty adult Port Said subjects from different regions were screened. Fifty nine of the 180 subjects $(32.8 \%)$ were positive for a modified OF-test. They all had significant CBC analysis as compared to the OFtest negative group. A successful identification of thalassemia using a $0.34 \%$ buffered saline OF-test prior to PCR-based genotyping on cell lysates was demonstrated. Among the 59 OF-test positive subjects, 8 resided unrelated cases were successfully observed to be thalassemic subjects. Our prospective study in 180 adult subjects confirms the expected incidence of $\alpha$ thalassemia and $\beta$-thalassemia types in Port Said limited population which has not been reported before. The purpose to study the incidence of thalassemia in Port Said is making it applicable to a large-scale screening program in Egypt population, to give more insight into the origin and thalassemia mutations underlying these incidences, and to meet the short and long term goals of thalassemia prevention and management.

Keywords: Modified osmotic fragility test, thalassemia, thalassemia incidence, whole blood PCR

\section{INTRODUCTION}

Thalassemias are $\mathrm{Hb}$ genetic disorders in which there is unbalanced synthesis of different globin chains (Angatiniotis and Modell, 1998) and thus excessive destruction of red blood cells. In a normal scenario, the $\alpha / \beta$-globin chains synthesis is $\sim$ 1.0. When there is an imbalance in the synthesis of globin chains, it is defined as thalassemia.

Thalassemia is classified according to the globin chain for which the synthesis is impaired, e.g. $\alpha$-thalassemia and $\beta$ thalassemia affecting the $\alpha$ - and $\beta$-globin chains respectively (Weatherall, 2001). The genes coding for $\alpha$-like and $\beta$-like globin chains are located on chromosome 16 and 11 respectively. The globin genes share a common structure consisting of three exons and two introns (Fig. 1). The intronexon junction is characterized by the presence of a conserved nucleotide sequence GU (“donor" splice sequence) at 5 ' end and AG ("acceptor" splice sequence) at 3 ' end (Feng et al., 1997; Orkin and Goff, 1981; Molchanova et al., 1994).

Thalassemias are caused by a diverse array of mutations. The $\alpha$-thalassemias are most commonly due to gene deletions while $\beta$-thalassemias are generally due to gene mutations at various sites of the $\beta$-cluster genome (Weatherall, 2001; Temtamy et al., 2009).

It is a life-threatening disease and each year hundreds of babies are born with $\alpha$-thalassemia as well as severe forms of $\beta$-thalassemia (Angatiniotis and Modell, 1998; Weatherall, 2001; Renzo et al., 2010). It is a fairly common single gene disorder (Flint et al., 1993) and its current therapy consists of frequent blood transfusions combined with iron chelation treatment to combat anemia. The only cure, bone marrow transplantation, is limited by the scarcity of suitable 
histocompatible donors (Lucarelli et al.; 1999; Shawky and Kamal, 2012). Over the last century, because of mass population migration around the world, the prevalence of the thalassemia has become a global issue with particularly high frequencies in the Mediterranean basin (Weatherall and Clegg, 1981). In Egypt, $\beta$-thalassemia is considered the commonest chronic hemolytic anemia (85.1\%) (Sabri, 1973; Rady et al., 1997; Shawky and Kamal, 2012). It is a significant public health problem in Egypt and the incidence varies from region to another. There is a high rate of consanguineous marriage in Egypt which helps to accumulate deleterious genes in families, reaching $35.3 \%$ with an average inbreeding coefficient of 0.019 which could be considered high (Shawky et al., 2011; Shawky and Kamal, 2012).

There are no published thalassemia-frequency data for Port Said, Egypt. Moreover, at the molecular basis the disease is not studied and the mutations not identified. The purpose of this study was to provide up-to-date information about the incidence of thalassemias and the nature of mutations that occurred in this Mediterranean basin city. This study reported successfully the incidence of thalassemias and analyzed mutations in Port Said governorate using complete blood counts (CBC), as well as a modified osmotic fragility test (OF-test) and a direct PCR on whole blood cell lysates.

\section{Materials and methods}

\section{Complete Blood Counts (CBC):}

One milliliter each of peripheral blood was put in standard EDTA-containing tube as anticoagulant and sent for complete blood count (CBC) in the Medical Lab El-Lwah, Saad Zaghloul St, Port Said, Egypt. One hundred fifty adolescent from both genders and fifty children aged 1-13 years (with a mean of 7 years) were sampled.

Our $\mathrm{CBC}$ tested the following parameters: hemoglobin ( $\mathrm{Hb})$ level, hematocrit (Hct), red blood cell (RBC) count, mean cell volume $(\mathrm{MCV})$, mean cell $\mathrm{Hb}(\mathrm{MCH})$, mean cell $\mathrm{Hb}$ concentration (MCHC) using the automated Sysmex KX-21N hematology analyzer (Sysmex corporation, Japan).

Leishman's-stained blood smears from each tube were evaluated under a light microscope as usual.

\section{Osmotic Fragility test (OF-test):}

The osmotic fragility test (OF-test) was done as described by Panyasai et al (2002). The test was applied to the groups of subjects who were also investigated for complete blood counts (CBC). A sample of $20 \mu 1$ whole blood was pipetted and mixed well with $2 \mathrm{ml}$ of $0.34 \%$ buffered saline solution at $\mathrm{pH}$ 7.4 and allowed to stand at room temperature for $15 \mathrm{~min}$ before interpretation. The tests were evaluated by visualization as negative and positive. Negative samples were characterized by a clear red hemoglobin solution indicating complete hemolysis of the red cells in the solution whereas positive samples were identified by a cloudy or smoky appearance because of incomplete hemolysis of the red cells (figure 1). Suspicious samples with a very fine cloudiness considered as positive. To estimate the percentage of hemolysis, the test tube was centrifuged for 5 minutes at $500 \mathrm{xg}$ and the hemoglobin in the supernatant solution was measured manually by absorbance (optical density) at $540 \mathrm{~nm}$ using UV-visible spectrophotometer. The results of the visualized interpretation and percentage of hemolysis in the solution were as follows: negative corresponded to 91 to $100 \%$ hemolysis and positive to 86 to $90 \%$ hemolysis. Means and standard deviations of the hematologic analysis data and the osmotic fragility test (OFtest) of the healthy and anemic values were calculated and then compared by a paired $t$-test.
Fig. 1. Interpretation of the osmotic fragility test (OF-test). Clear (left: negative test) or turbid (right: positive test) solution, based on readable or unreadable black texts on the white background paper.

\section{DNA Extraction:}

DNA samples were prepared from whole peripheral blood of subjects using the Blood DNA Preparation Kit, Jena Bioscience, Egypt. $900 \mu 1 \mathrm{RBC}$ Lysis Solution was added to $300 \mu 1$ of whole blood in $1.5 \mathrm{ml}$ microcentrifuge and vortexed and centrifuged at 15,000 rpm for $1 \mathrm{~min}$. The supernatant was removed by suction up to about $20 \mu \mathrm{l} ; 1 \mathrm{ml}$ of water was added, after centrifugation for $1 \mathrm{~min}$ as above, the supernatant was removed again up to about $20 \mu 1$ and vortexed. $300 \mu 1$ Cell Lysis Solution was added and vortexed. From a Jena Bioscience, Blood DNA Preparation Kit, $100 \mu$ l Protein Precipitation Solution was added to the suspension and vortexed vigorously for 30 seconds to mix well and centrifuged at $15,000 \mathrm{rpm}$ for $1 \mathrm{~min}$. The supernatant was transferred into a cleaned $1.5 \mathrm{ml}$ microcentrifuge containing $300 \mu \mathrm{l}$ isopropanol $>99 \%$ and then vortexed and centrifuged again at $15,000 \mathrm{rpm}$ for $1 \mathrm{~min}$. The DNA white pellets were taken and kept at $4{ }^{\circ} \mathrm{C}$ until they were used as templates in PCR.

\section{Polymerase Chain Reaction (PCR):}

For PCR, all amplifications were made in final volumes of 50 $\mu 1$ with $40 \mu 1$ of PCR TaqMan Master Mix (Applied Biosystems), contained $1 \mu 1$ each of the 2 sets of amplification primers (figure 2) at a final concentration of $1 \mathrm{pmol}$ and $4 \mu \mathrm{l}$ of genomic DNA template $(0.075 \mu \mathrm{g} / 1 \mu \mathrm{l})$. We optimized the PCR in a way that all primers can be used in one single amplification reaction. The PCR tubes were placed in a thermal Cycler (Perkin-Elmer). When the temperature in the block reached $94{ }^{\circ} \mathrm{C}$ and were kept at that temperature for 2.5 min for strand separation. After that, 35 cycles of amplification were performed. The cycle of denaturation at 94 ${ }^{\circ} \mathrm{C}$ for $0.5 \mathrm{~min}$, annealing at $58{ }^{\circ} \mathrm{C}$ for $1 \mathrm{~min}$ and extension at $72{ }^{\circ} \mathrm{C}$ for $1 \mathrm{~min}$. When the last cycle was completed, the reactions were kept for another $5 \mathrm{~min}$ at $72{ }^{\circ} \mathrm{C}$. The total amount of PCRs was analyzed by electrophoresis on $2 \%$ agarose gels containing $0.5 \mu \mathrm{g} / \mathrm{ml}$ of ethidium bromide; the DNA bands were detected by UV light and documented using a Biorad gel doc 1000 system. All products obtained were sized using a standard 100-bp molecular weight ladder.

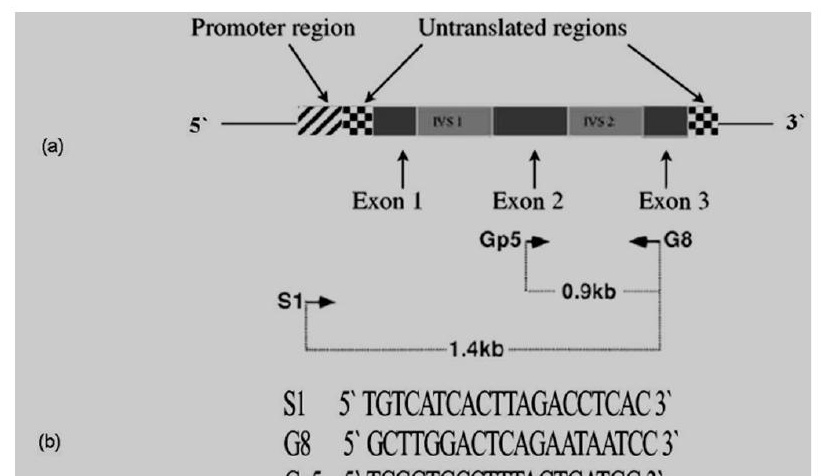


Fig. 2. (a) Schematic structure of human globin gene with three exons separated by two intervening sequences (IVS). The location and direction of amplification primers are shown. (b) Nucleotide sequences of each primer. S1 + G8 and Gp5 + G8 which span the 1.4 and $0.9 \mathrm{~kb}$ regions respectively.

Direct Sequencing of Amplified DNA:

Direct sequencing of PCR amplified genomic DNA samples was performed. Briefly, the amplified products obtained by a single amplification reaction were extracted once with ethanol precipitation after the phenolchloroform treatment. Direct sequencing of the PCR products was performed with the automatic sequencing assay using the Perkin-Elmer ABI 3700 DNA sequencer following the manufacturer's protocol for the sequencing reaction. One strand of DNA was sequenced. The sequencing results have been further grouped and analyzed.

\section{Results}

\section{Complete Blood Counts (CBC):}

The majority of the $\mathrm{Hb}$ variants do not infer any specific morphological features to the erythrocytes and the complete blood count (CBC) may well present normal. Although there is no simple phenotypic test available for the detection of thalassemia, the red cell indices are important indicators in the assessment of mild thalassemia characterized by normal or slightly subnormal $\mathrm{Hb}$ levels. Reduced mean corpuscular volume $(\mathrm{MCV}<72 \mathrm{fL})$ of red cells and mean corpuscular hemoglobin $(\mathrm{MCH}<27 \mathrm{pg})$ are indicative of possible thalassemia (Clarke and Higgins, 2000; Traeger-Synodinos et al., 2002)

One hundred fifty adolescent of both genders from unrelated Port Said families were sampled along with fifty children aged 1-13 years. Tests performed for the detection of hemoglobin variants included Leishman's-stained blood smears from each subject. Results of the tests for hemoglobin variants are summarized in table 1. Among the One hundred fifty adults only fifty seven $(38 \%)$ in male and female were anemic subjects. Eighteen adults (13 males, 5 females $)$ had significantly lower microcytic MCV ( $<72 \mathrm{fL})$ of red cells and hypochromic MCH $(<27 \mathrm{pg})$ as compared to those of the 132 adult subjects $(\mathrm{p}<0.001)$ which indicative of possible thalassemia incidence in the genetics of a Port Said population and generally regarded as a case of further tests. None were transfusion-dependent but most had been transfused sporadically. Inclusion bodies and hypochromic red blood cells were readily detected by Leishman's-stained blood smears from each. The results of hemoglobin variants in children are shown in table 2. Gender in children does not detect any significance difference by t-test, and therefore these are not included in table 2. The parameters: hemoglobin $(\mathrm{Hb})$ level, hematocrit (Hct), red blood cell (RBC) count and mean cell $\mathrm{Hb}$ concentration (MCHC) did not differ significantly between study groups.

Table 1. Results of hematologic values in normal adults compared with anemic adults in Port Said subjects.

\begin{tabular}{|c|c|c|c|c|}
\hline \multirow{2}{*}{$\begin{array}{c}\text { Gender/A } \\
\text { ge (yr) } \\
\text { Analysis } \\
\text { data }\end{array}$} & $\begin{array}{c}\text { norm } \\
\text { al } \hat{\sigma} \\
>13\end{array}$ & $\begin{array}{c}\text { affect } \\
\text { ed } \widehat{0} \\
>13\end{array}$ & $\begin{array}{c}\text { norm } \\
\text { al } q \\
>13\end{array}$ & $\begin{array}{c}\text { affect } \\
\text { ed } q \\
>13\end{array}$ \\
\hline & $\begin{array}{c}n= \\
75\end{array}$ & $n=26$ & $\begin{array}{c}n= \\
75\end{array}$ & $n=31$ \\
\hline $\begin{array}{c}\text { RBCs (X } \\
\left.10^{12} / /\right)\end{array}$ & $\begin{array}{c}4.6 \pm \\
0.5\end{array}$ & $\begin{array}{l}3.8 \pm \\
0.34\end{array}$ & $\begin{array}{l}4.4 \pm \\
0.26\end{array}$ & $\begin{array}{c}4.01 \pm \\
0.16\end{array}$ \\
\hline $\mathrm{Hb}(g / d l)$ & $\begin{array}{c}13.98 \\
\pm \\
0.17\end{array}$ & $\begin{array}{l}9.5 \pm \\
0.6 ¥\end{array}$ & $\begin{array}{r}12.8 \\
\pm 0.2\end{array}$ & $\begin{array}{c}8.8 \pm \\
0.24 ¥\end{array}$ \\
\hline Hct $(\%)$ & $\begin{array}{c}43.03 \\
\pm 1.1\end{array}$ & $\begin{array}{c}29.9 \pm \\
2.7 ¥\end{array}$ & $\begin{array}{l}39.2 \\
\pm 2.2\end{array}$ & $\begin{array}{r}28.5 \pm \\
0.9 ¥\end{array}$ \\
\hline $\operatorname{MCV}(f L)$ & $\begin{array}{r}85.3 \\
\pm 1.4\end{array}$ & $\begin{array}{c}74.3 \pm \\
4.2\end{array}$ & $\begin{array}{r}84.7 \\
\pm 2.7\end{array}$ & $\begin{array}{r}72.8 \pm \\
1.9 ¥\end{array}$ \\
\hline $\mathrm{MCH}(p g)$ & $\begin{array}{r}30.6 \\
\pm 0.9\end{array}$ & $\begin{array}{c}26.6 \pm \\
1.6\end{array}$ & $\begin{array}{l}29.03 \\
\pm 1.3\end{array}$ & $\begin{array}{c}22.5 \pm \\
0.9 ¥\end{array}$ \\
\hline $\begin{array}{c}\mathrm{MCHC} \\
(g / d l)\end{array}$ & $\begin{array}{r}34.1 \\
\pm 0.7\end{array}$ & $\begin{array}{c}31.7 \pm \\
0.6\end{array}$ & $\begin{array}{r}31.6 \\
\pm 1.3\end{array}$ & $\begin{array}{c}31.4 \pm \\
0.8\end{array}$ \\
\hline
\end{tabular}

$n$ number of individuals tested

numbers represent means \pm SE values ( $\mathrm{n}$ $=75)$

$¥$ Significant according to unpaired $t$-test $(\mathrm{P} \leq 0.01)$ 
Preliminary observations on tissue polypeptide pattern indicated the differences between infected and control snails by both qualitative and quantitative techniques. The total protein contents of B.alexandrina generally decreased significantly as a result of infection. While, the total protein contents of B.glabrata increased due to infection compared with control group. Loker and Hertel (1987), revealed a significant increase in total protein in the plasma of B.glabrata infected for 4 and 8 days with Echinostoma paraensei. Previous studies on B.glabrata infected with Schistosoma mansoni indicated that after 11-14 days of infection, the plasma protein content of infected snails is significantly reduced (Lee and Cheng, 1972; Gress and Cheng, 1973; Michelson and Dubois, 1975; Stanislawski and Becker, 1979). So, those previous studies are tolerant with the present study of infected B.alexandrina. While, total protein of infected B.glabrata in the present study is coordinated with the results of Loker and Hertel (1987). Schistosoma mansoni therefore seems to evoke different response in different hosts as B.alexandrina or B.glabrata.

The electrophoretic pattern by SDS-PAGE revealed that, there were 13 different protein bands with molecular weights ranged from 15-300 KDa. Each group has a specific band, B.alexandrina has a specific band with $300 \mathrm{KDa}$, whereas, B.glabrata has a specific bands with molecular weights of 75 and $65 \mathrm{KDa}$. A band with molecular weight of $180 \mathrm{KDa}$ in the present study considered to be hemoglobin similar to that described previously by Loker and Hertel (1987). In contrary, Granath et al. (1987) described this band with molecular weight of $160 \mathrm{KDa}$. This band with $180 \mathrm{KDa}$ diffused completely in 14 days postexposure to parasite in both Biomphalaria species, this may be due to consumption of hemoglobin by parasite after prolonged exposure to S.mansoni. Uchikawa and Loker (1992), designed a group of molecules G1M (200 KDa) and G2M (80-120 KDa) as a response to infection with Echinostoma paraensei. But in the present study there were only two bands ( 275 and $150 \mathrm{KDa})$ appeared in B.glabrata after prolonged exposure (14 days) to parasite. A band with molecular weight of $65 \mathrm{KDa}$ appeared in both control and 7days PE. B.glabrata and disappeared in 14 days PE.

Adema et al. (1997 a \& b) demonstrated that 65 KDa band appeared in infected B.glabrata, and this band was strongly bound by anti-fibrinogenes antibodies, comprised of at least two members of the fibrinogene related protein (FREPs) and responsible for the internal defence of the snail. Also FREPs have been identified by Stout et al. (2008). These apparent bands indicate the presence of immune polypeptides that bind to protein of S.mansoni miracidia and sporocyst and ensured by the study of previous authors who demonstrated that FREPs, G1M, and G2M may agglutinate different types of erthrocytes and other particulate materials or bind protein of echinostome miracidia and sporocyst both in vivo and in vitro (Hertel et al., 1994 and Locker et al., 1994). The 35 and 15 $\mathrm{KDa}$ protein bands of the present study appeared in B.alexandrina and B.glabrata only 7 days PE respectively.

According to similarity matrix in the present study, there is an obvious high similarity index $(S=0.8)$ between the two species of Biomphalaria, despite of their morphological and molecular differences. Also higher values of similarity indices $(S=0.8 \&$ 0.75 ) obtained between all the groups of B.glabrata compared to control. However, moderate values of similarity $(S=0.5 \&$ o.6) obtained between B.alexandrina groups compared to control. El- Dafrawy et al. (2006) demonstrated the highest similarity index 0.667 , in 2 weeks and 5 weeks post exposure to S.mansoni miracidia groups of B. alexandrina and the lowest one was in 3-days post exposure (0.5) compared to control group.

\section{References}

Adema, C.M.; Hertel, L.A.; and Loker, E.S. (1997a). Infection with Echinostoma parensei (Digenea) induces parasitereactive polypeptides in the hemolymph of the gastropod host B.glabrata. In Parasite effects on host physiology and Behavior (ed. N. Beckage), pp. 77-99. Chapman press, New York.

Adema, C.M.; Hertel, L.A.; Miller, R.D.; and Loker, E.S. (1997b). A family of fibrinogen related proteins that precipitates parasite derived molecules is produced by an invertebrate after infection. Proceeding of the National Academy of Science, USA 94: 8691-8696.

Bakry, F. (2009).Genetic varation between Biomphalaria alexandrina and Biomphalaria glabrata snails and their infection with Egyptian strain of Schistosoma mansoni. Journal of Applied Sciences Research, 5(9): 1142-1148.

Bradford, M. (1976) .A Rapid and Sensitive Method for the Quantitation of Microgram Quantities of Protein Utilizing the Principle of Protein-Dye Binding. Analytical Biochemistery 72:248-254.

Brown, S. D. (1994). Freshwater snails of Africa and their medical importance. Second edition. London: Taylor and Francis, 200.

Dice, L.R., 1945. Measures of the amount of ecological association between species. Ecology. 26: 247-302.

El-Dafrawy, S.M, El-Din, A.T, Hamid H.A. (2006). Electrophoretic patterns of protein fractionations in hemolymph and tissues of Biomphalaria alexandrina and Bulinus truncatus during course of schistosome infection. Journal of Egypt Society and Parasitology 36(3):795-807.

Fryer, S. E.; Hull, C. J.; and Bayne, C. J. (1989). Phagocytosis of yeast by B. glabrata carbohydrate specifity of hemocyte receptors and a plasma opsonin. Developmental and Comparative Immunology. 13: 9-16.

Granath, W.O.; Spray, F. J., and Judd, R. C. (1987). Analysis of B.glabrata (Gastropoda) hemolymph by sodium dodecyl sulphate polyacrylamide gel electrophoresis, high performance liquid chromatography and immunoblotting. Journal of Invertebrate Patholology. 49(2): 198-208.

Gress,F.M., and Cheng, T. C. (1973). Alteration in total serum proteins and protein fractions in Biomphalaria glabrata parasitized by Schistosoma mansoni. Journal of Invertebrate Patholology. 22: 382-390.

Hertel, L. A.; Stricker, S. A.; Monroy, F. P.; Wilson, W. D.; and Loker, E. S. (1994). B.glabrata hemolymph lectins: binding to bacteria, mammalian erythrocytes, and to sporocysts and rediae of Echinostoma paraensei. Journal of Invertebrate Patholology. 64: 52-61.

Hickman, C. P. (2000). Mollusca. In Animal Diversity (2nd edn), p. 448, McGraw Hill.

Laemmli, U. K. (1970). Cleavage of structural proteins during the assembly of the head of bacteriophage T4. Nature, 227:680-685. 
Lee, F. O., and Cheng, T. C. (1972). Schistosoma mansoni: Alteration in total protein and hemoglobin in the hemollymph of infected Biomphalaria glabrata. Experimental Parasitology 31: 203-216.

Loker, E. S., and Hertel, L. A. (1987). Alteration in B.glabrata plasma induced by infection with the digenetic trematode Echinostoma paraensei. Journal of Parasitology.73(3):503513.

Loker, E. S.; Couch, L.; and Hertel, L. A. (1994). Elevated agglutination titres in plasma of B.glabrata exposed to Echinostoma paraensei: characterization and functional relevance of a trematode-induced response. Parasitology 108: 17-26.

Lotfy. W. H; Dejong. R. J.; Black, B. S.; and Loker, E. S. (2005).Specific identification of Egyptian Biomphalaria species and possible hybrids using the polymerase chain reaction based on nuclear and mitochondorial loci. Molecular and Cellular Probes. 19: 21-25.

Malek, E. A. (1985). Snail hosts of schistosomiasis and other snail transmitted disease in tropical America: a manual. Pan American Health Organziation Scientific Publication No. 478. PAHO, Washington.

Michelson, E. H., and Dubois, L. (1975). Intraspecific variations in the hemolymph of Biomphalaria glabrata, a snail host of Schistosoma mansoni. Malacologia 15: 105-111.

Richard, E. H., and Renwrantz, L. R., (1991). Two lectins on the surface of Helix pomatia hemocytes: a $\mathrm{Ca}++$-dependent, Gal Nac-specific lectin and a Ca++- independent, mannose 6phosphate specific lectin which recognizes activated homologous opsonins. Journal of Comparative Physiology. B 161: 43-54.

Stanislawski, E., and Becker, W. (1979).Influences of semisynthetic diets, starvation and infection with Schistosoma mansoni (Trematoda) on the metabolism of Biomphalaria glabrata (Gastropoda). Comparative Biochemistery and Physiology. 63 A: 527-533.

Stout, B.; Adema, C.M.; Zhang, S.M, and Lokers E.S. (2008).The biology of FREPs:diversifled lectins with fibrinogen related domains from the freshwater snail B.glabrata. In: Vasta GR, Ahmed H. (eds) Animal lectins: A functional view. Cleveland, OH: CRC Press Taylor\&Francis; In Press.

Sturrock, R.F. (2001).Schistosomiasis epidemiology and control: how did we get

here and where should we go?. Mem. Inst. Oswaldo Cruz 96 (Suppl.), pp.17-27.

Uchikawa, R., and Loker, E. S. (1992). Echinostoma paraensei and $S$. mansoni-adherence of unaltered or modified latex beads to hemocytes of the host snail B. glabrata. Expermintal Parasitology 75: 223-232.

Van der Knaap, W.P.W. and Loker, E.S. (1990). Immune mechanisms in trematode snail interactions. Parasitology Today 6: 175-182.
Yoshino, T.P. and Vasta, G. R. (1990). Parasite-invertebratee host immune interactions. In Advances in Comparative and Environmental Physiology, Vol.24 (Ed. Vasta, G.R.), pp.125167. Springer Verlag, Berlin.

Yousif, F.; Haroun. N.; Ibrahim A., and El-Bardicy, S., (1996). Biomphalaria glabrata: a new threat for schistomiasis transmission in Egypt. Journal of Egypt Society and Parasitology 26: 191-205.

Zhang, S. M; Zeng ,Y., and Loker ,E. S. (2008).Expression profiling and binding properties of fibrinogen- related proteins (FREPs), plasma proteins from the schistosome snail host B.glabrata. Innate Immunity 14(3): 175-189. 


\section{الملخص العربي \\ "ألاختلافات النوعيه بين قوقع بيومفلاريا الكسندرينا و بيومفلاريا جلابراتا في وجود و غياب البلهارسيا المعويه باستخدام تحليل البروتين."}

تعتبر البلهارسيا من أكثر الامر اض الثائعه في مصر منذ قديم الاذل. و قد نم التعرف علي نوعين من القواقع هما بيومفلاريا

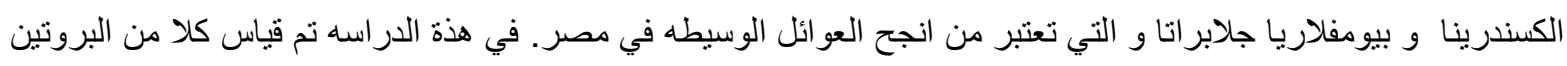

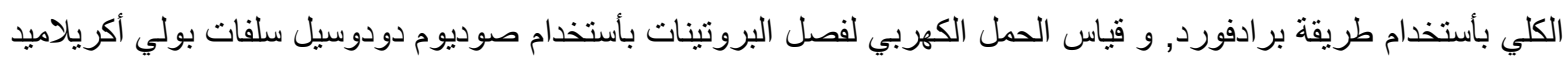

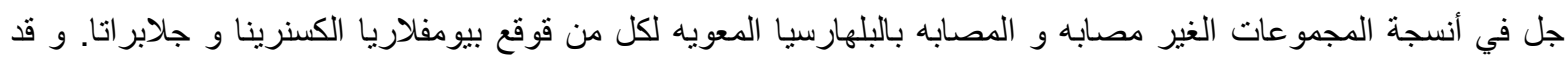

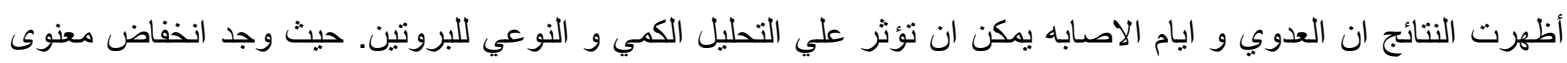

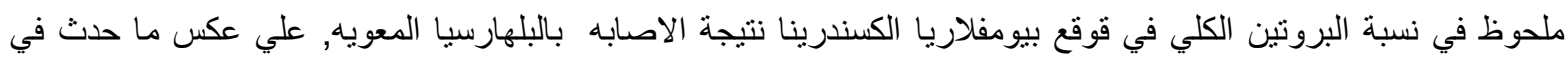

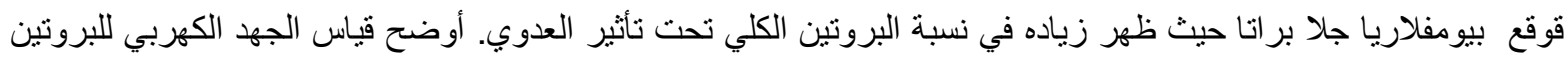

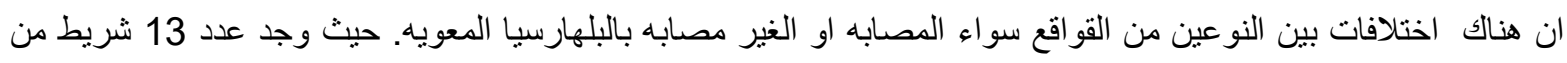
البروتينات لها اوزان تتراوح بين 15-300 كيلو دالتون, مع وجود أشرطه مميزه لكل مجموعه. و قد اوضحت مؤشرات

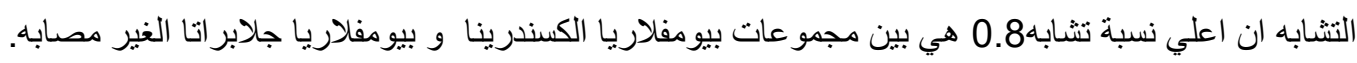
تعتبر هذه الدراسه هي محاوله لتعريف الانواع المتشابهه من الحيوانات باستخدام تقنيات حديثه و بسيطه بدلا من الطرق القديمه لفيه التي تعتد علي الثكل الظاهري فقط. و ايضا اكتشفت الدراسه تنوع في اشرطة البروتين نتيجة الاصابه بالبالهارسيا المعويه. 